\title{
PEREMPUAN DAN KEKERASAN: Memposisikan Konsep Kekerasan Perspektif al-Qur'an
}

M. Fauzan Zenrif, M.Ag. Dosen tetap STAIN Malang

M. Fauzan Zenrif, M.Ag. Lahir di Malang, 6 September 1968. Pada tahun 1998 ia telah tamat dari S2 di Ujung Pandang. Selanjutnya diangkat menjadi dosen tetap STAIN Malang dengan keahlian

Pemikiran Keislanian. Aktif mengikuti diskusi rutin dosen muda STAIN Malang. Aktif pula melakukan penelitian dan penulisan-penulisan artikel ilmiah pada beberapa majalah dan jumal.
Diskursus keperempuanan memang selalu aktual, tak habishabisnya dan tak bosan-bosannya dididiskusikan. Seperti makan, sekarang merasa kenyang nanti merasa lapär dan makan lagi. Begitu juga diskusi mengenai keperempuanan, ketika kita jenuh dengan masalah emansipasi, kemudian kita berbicara feminisme dan kesataraan jender, sekarangpun sedang hangat didiskusikan masalah kekerasan terhadap perempuan. Masalah yang disebutkan terkahir ini, dalam pandangan banyak orang disebabkan konstruksi sosial yang patriarkal. Untuk itulah, masalah ini sering juga disebut dengan gender.based violence. ${ }^{1}$

Emansipasi, feminisme dan terkahir analisis kesataraan jender sesungguhnya merupakan upaya untuk mengangkat harkat kemanusiaan perempuan di depan atau di samping mitranya, laki-laki. Puncak perjuangan tersebut secara konstitusional dirasakan kaum perempuan dengan diterbitkannya Deklarasi tentang Penghapusan Kekerasan terhadap Perempuan, pada bulan Desember tahun 1994 oleh Perserikatan Bangsa Bangsa. Di Indonesia, masalah kekerasan terhadap perempuan, khususnya yang berkaitan dengan sexual violence, dirumuskan dalam Kitab Undang-undang Hukum Pidana (KUHP) dalam Buku IIBab XIV pasal 281 sampai pasal 303, dan Buku III Bab VI pasal 532 sampai 547, tentang kejahatan terhadap kesusilaan dan Pelanggaran Kesusilaan.

Kekerasan dalam perspektif Barat berbeda dengan perspektif al-Qur'an. Sementara Barat memandang kekerasan sebagai fenomena sosial, ${ }^{2}$ sebab mereka menggunakan pendekatan positivistik, terlepas dari kekuatan normatifnya. Al-Qur'an memandang kekerasan dengan meriggunakan pendekatan normatif. Untuk itu, kekerasan perspektif al-Qur'an adalah perilaku yang disebabkan oleh hati yang keras (ghalidh al-qalb) sebagai akibat dari penolakannya terhadap petunjuk Allah swt (hidayah). Dalam al-Qur'an ghalidh al-qalb diidentifikasi sebagai nurani yang sakit (maridl al-qalb). ${ }^{3}$ Manusia yang demikian mudah melakukan perilaku kejahatan. 
Dalam palndangan demikian; Islam melihat bahwa kekerasan identik dengan kejahatan. Dimana kejahatan yang dilakukan tersebut dapat berbentuk dua model perilaku. Pertama, Perilaku kejahatan yang tidak secara langsung berdampak pada orang lain, lebih berdampak personal. Perilaku yang dimaksud adalah kekufuran (tidak bersyukur), ${ }^{4}$ tergesatergesa (dalam berbuat dan mengambil kesimpulan atau keputusan), lekas putus asa, kafir ketika berada dalam kekuasaan (menggunakan kekuasaan secara tidak adil), bangga dan sombong ketika dalam keadaan makinur, ${ }^{6}$ dan lain-lain. Model ke ahatan ini disebut al-Qur'an dengan menggunakan term fakhisyah atau fakhsya'dan khabits.

Kedua, perilaku kejahatan yang sècara langsung berdarnpak pała orang lain atau pada lingkungannya, seperti suka betbantah-bantahan (baik sekedar berdebat maupun hingga menimbulkan konflik soșial)," suka mengkonsumsi narkoba atau melakukan perjudian, ${ }^{8}$ perzinahan (sekalipun didasarkan atas kemaun bersama), ' dan sebagainya. Kejahatan seperti ini disebut dengan fasad, munkar dan syarr. ${ }^{10}$

Kedua bentuk kejahatan, tepatnya kekerasan, tersebut harus dijauhi oleh umat Islam, karena sekecil apapun kejahatan yang dilakukan tetap merupakan kekerásan yang dianggap bettentangan dengan nilai-nilai kemanusian yang dikehendaki Isląm. Menggunjing orang lain, atau komunitas dari kelompok lain, baik dilakukan secara personal maupun kolektif dalam term humanisme (selain Islam) bisa dianggap bukan suatu kekerasan. Untuk itu, hingga saat ini belum ada perudang udangan yang mengatur tentang hal itu. Akan tetapi; Islam melihat bahwa dampak dari pergunjingan, apalagi dilakukan dengan jalan terbuka, akan berdampak negatif, atau bahkan konflik sosial. Sebab itulah, al-Qur'an melarang pergunjingan baik dilakuakn 'secara personal maüun kolektif."

Akan tetapi; Islam, dan bahkan agama-agama samawi yang lain sekalipun, berbeda dengan pandangan Barat sementara ini, memandang Perang Suci (sabilillah) bukan sebagai suatu tindak kekerasan, selama perang tersebut dilakukan dengan tetap memperhatikan ketentuan-ketentuan agama: Tegasnya, Islam melihat kekerasan tidak hanya perilaku-perilaku yang secara langsung dapat berdampak negatif pada orang lain. Kekerasan dalam perspektif agama yang diajarkan dan dibawa Muhammad saw. ini adalah seluruh inodel kejahatan yang dilakukan
Menggunjing orang lain, atau komunitas dari kelompok lain, baik dilakukan secara personal maupun kolektif dalam term humanisme (selain Islam) bisa dianggap bukan suatu kekerasan. Untuk itu; hingga saat ini belum ada perudang-udangan yang mengatur tentang hal itu 
Kebenaran konsep

al-Qur'an tentang potensi kekerasan perempuan ini didukung fakta sosial di beberapa negara Barat.DI Amerika, kejahatan perempuan kian tahun kian mening kat. Bahkan, Adler menilai kekerasan yang dilakukan oleh perempuan jauh lebih cepat meningkat diban dingkan yang dilakukan oleh laki-laki. manusia, baik secara langsung berdampak pada orang lain atau tidak, baik dilakukan secara personal maupun kolektif. Akan tetapi, perang dalam rangka mempertahankan diri atau mempertahankan agama tidaklah dikategorikan sebagai suatu tindak kekerasan.

Kekarasan yang disebutkan tadi, bisa dilakukan baik oleh laki-laki maupun perempuan, bukan monopoli laki-laki, bergantung kepada kematangan religiositasnya masing-masing individu. Al-Qur'an bahkan mengabadikan kekerasan seorang perempuan yang bernama Arwa. Perempuan yang digelari dengan Ummu Jamil ini adalah putrid dari Harb, saudara perempuan Abu Sufyan bin Harb, dan salah seorang isteri dari Abu Lahab. Dalam al-Qur'an perempuan ini digelari dengan "Hammalah al-Hathab" sebab ia suka membawa berita-berita bohong yang berakibat pada perpecahan antara sesama manusia, atau, dalam pendapat lain, sebab ia berperilaku buruk dengan membawa kayu-kayu yang berduri untuk ditabur di jalan-jalan yang dilalui olèh Beliau Muhammad saw. ${ }^{12}$ Islam memandang bahwa setiap individu mempunyai potensi berperilaku kekerasan.

Sangsi perilaku kekerasan yang disebutkan di atas, baik sangsi hukum maupun moral, juga meliputi laki-laki dan perempuan. Misalnya saja, kepemilikan kekayaan (uang dan sejenisnya) secara tidak sah (pencurian atau perampasan) atau disebut juga dengan property crime, ${ }^{13}$ kekerasan seksual (sexual violence), ${ }^{14}$ dan pembunuhan. ${ }^{15}$

Kebenaran konsep al-Qur'an tentang potensi kekerasan perempuan ini didukung fakta sosial di beberapa negara Barat.DI Amerika, kejahatan perempuan kian tahun kian meningkat. Bahkan, Adler menilai kekerasan yang dilakukan oleh perempuan jauh lebih cepat meningkat dibandingkan yang dilakukan oleh laki-laki. ${ }^{16}$ Kriminalitas perempuan tersebut tidak hanya pembunuhan, perampokan, penganiayaan, pembongkarar dan pencurian, penjambretan, pencopetan dan pembakaran rumah, tapi juga perkosaan disertai kekerasan. ${ }^{17}$

Perilaku aneh seksualitas perempuan selibriti dapat terlihat dengan jelas pada peri laku Michella Pliffer and Melanie yang berpasangan dengan laki-laki yang lebih muda darinya. Bahkan, Madonna sering berganti-ganti pasangan yang mayoritas lebih muda darinya. Alexander Hakan, seorang penari erotis, berkata pada New York Times bahwa dia sering kena cakar kuku 
petempuan yang selalu mencoba membuka celana dalamnya. ${ }^{18}$

Di Belanda; ada infromasi bahwa konglomerat perempuan asal Eropa bagian Utara biasa menggunakan laki-laki muda sebagai "mainan seksual" mereka dalam perjalanan bisninya, dap setelah puas laki-laki muda tersebut dicampakkan begitu saja di jalanan yang dingin tampa baju penghangat. Di Rio de Jeneiro, Brasilia, ada sepuluh night club yang khusus menawarkan penari laki-laki tanpa busana. ${ }^{19}$

Berikut ini data penahanan perempuan karena indeks keiahatan pada tahun 1986-1989:

Sumber: U.S. Departemen of Justice, Federal Bureu of Inyestigation, Crime in the United States 1986 (Washington, DC.: USGPO, 1988), h. 173; U.S. Departemen of Justice, Federal Bureu of Investigation, Crime in the United States 1989 (Washington, DC.: USGPO, 1990), h. 181, seperti dikutip dalam Jane C. Ollenburger dan Helen A. Moore, A Sociology of Women.

Angka-angka kekerasan perempuan di atas cukup mencekam bagi masa depan manusia. Bahkan, angka-angka tersebut juga diikuti oleh tingkat kriminalitas perempuan di seluruh dunia. Peningkatan kriminalitas tersebut, menurut Pollak, merupakan dampak negatif dari keberdayaan perempuan. Sebab, katanya lebih lanjut, beban fungsi-fungsi sosial perempuan yang bertambah, juga dapat meningkatkan kesempatan-kesempatan melakukan kejahatan. ${ }^{20}$

Apabila tesis Pollak ini benar adanya, maka kita perlu merekonstruksi konsep pemberdayaan perempuan yang dapat menghilangkan, atau setidaknya meminimalisir, kemungkinan ter adinya polarisasi kekerasan perempuan. Sebab, kita dapat melihat dengan jelas di Indonesia fenomena kekerasan pecempuan, baik dalam keluarga maupun publik, semakin transparan. Kita perlu memberdayakan perempuan dengan tidak harus menjadikan laki-laki tidak berdaya. Kita perlu menghilangkan kekerasan laki-laki tyerhadap perempuan dengan tidak harus menjadikan laki-laki sebagai sasaran kekerasan berikutnya. Sebab, dalam pandangan al-Qur'an, kekerasan pada siapapun, jenis kelamin apapun, dan pada kelompok manapun, tidak dibenarkan dan bertentangan dengan nilai-nilai kemanusiaan. Jika pemberdayaan perempuan dalam rangka
Apabila tesis Pollak ini benar adanya, maka kita perlu merekonstruksi konsep pember dayaan perempuan yang dapat menghi langkan, atau setidaknya memini malisir, kemung kinan terjadinya polarisasi keke rasan perempuan 
Kita perlu

memberdayakan perempuan dengan

tidak hanus

menjadikan lakilaki tidak berdaya.

Kita perlu

menghilangkan kekerasan laki-laki tyerhadap perempuan dengan tidak harus menjadikan lakilaki sebagai sasaran kekerasan berikutnya. Sebab, dalam pandarigan al-Qur'an, kekerasan pada siapapun, jenis kelamin apapun, dan pada kelompok manapun, tidak dibenarkan dan bertentangan dengan nilai-nilai kemanusiaan mengangkat harkat dan martabatnya sebagi manusia, maka lakilaki pun adalah manusia. Jika permberdayaan perempuan adalah demi pelaksaan agaam yang benar dan sesuai dengan tuntunan Nabi saw., maka sesungguhnya agama pun melarang kekerasan ini derigan tidak memandang jenis kelamin. Satu hal yang saya rasa perlu dicatat di sini, bahwa "Kekerasan dalam perspektif Barat berbeda dengan perspektif al-Qur'an". Tentunya, kita memilih perspektif al-Qur'an sebagai wacana kita, bukan malah sebaliknya! Wallahu a'lam bi ma na'lam wa ma lam na'lam, wa ila Allahi turja'u kullu amrin dzi balin.

\begin{tabular}{|l|l|l|l|l|}
\hline Modus Operandi Kejahatan & 1986 & 1983 & $\begin{array}{l}\text { PERSENTASE } \\
\text { PERUBAHAN }\end{array}$ & Kenaikan (N \\
\hline Pembunuhan & 1.957 & 1.989 & $+1,6$ & +32 \\
Perkosaan disertai kekerasan & 333 & 325 & $-2,4$ & -8 \\
Perampokan & 9.633 & 10.682 & +10.9 & +1.049 \\
Serangan Penganiayaan & 36.503 & 43.215 & $+18,4$ & +6.712 \\
Pembongkaran dan Pencunan & 28.479 & 29.332 & $+3,0$ & +853 \\
Penjambretan dan Pencopetan & 347.168 & 351.647 & $+1,5$ & +4.479 \\
Pencurian Kendaraan Bermotor & 12.028 & 17.502 & $+45,5$ & +5.474 \\
Pembakaran Rumah & 1.992 & 1.826 & $-8,3$ & -166 \\
Kejahatan Kekerasan & 48.426 & 56.211 & $+16,1$ & \\
Kejahatan terhadap Hak Milik & 389.667 & 400.307 & $+2,7$ & \\
Total Indeks Kejahatan & 438.420 & 456.518 & $+4,1$ & \\
\hline
\end{tabular}

\section{DAFTAR PUSTAKA}

'Diskusi mengenai hal ini baca Julia Cleves Mosse, "Half the World, Half a Chance: An Introduction to Gender and Development:, diterjemahkan oleh Hartian Silawati dengan judul, Gender dan Pembangunan (Yogyakarta: Pustaka Pelajar, 1961), h. 76 dst.

${ }^{2}$ Mengenai hal ini baca kembali Mudjia Rahardjo, "Kekerasan dan Kekuasaan dalam Praksis Bahasa: Memahami Kekerasan dalam Perspektif Galtung", dan M. Djunaidi Ghony, "Agama dan Kekerasan Massa", dalam eL-Harakah, Nomor 55, Tahun XXI, April-Juni 2000, h. 3-17.

${ }^{3}$ Dalam hal ini al-Qur'an menggunakan term fi qulubihim maradl. Term ini disebutkan sebanyak 12 kali dalam 9 surat. Lihat Muhammad Fu'ad 'Abd al-Baqy, al-Mu'jam al-Mufahras 